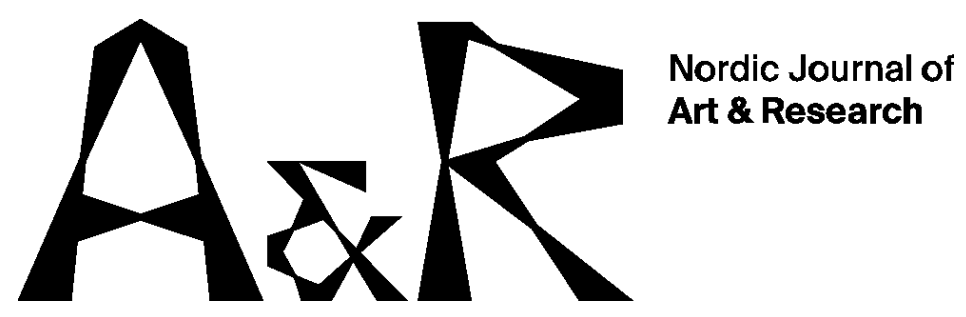

\title{
Eit skilt som prøver å vera eit skilt
}

\section{Om kunstproduksjon i samarbeid mellom små og store vesen}

\author{
Merete Jonvik ${ }^{1}$ \\ Universitetet i Stavanger
}

\section{Samandrag}

I kunst- og forskingsprosjektet Samarbeid mellom små og store vesen samarbeida ei gruppe born og ein kunstnar om å skapa eit kunstverk. Intensjonen med prosjektet var å utforska om likeverd og horisontalitet i kunstproduksjon beståande av asymmetriske relasjonar er mogleg. Med bakgrunn i deltakande observasjon, intervju og fotodokumentasjon drøfter artikkelen ulike former for samarbeid som viste seg $\mathrm{i}$ kunstproduksjonsprosessen, og kunstverket som kom ut av samarbeidet. Utforskinga av om likeverd og horisontalitet er mogleg i samarbeid mellom store og små i kunstproduksjon syner at forsøka enda nettopp som forsøk på horisontalitet, snarare enn faktisk horisontalitet. Artikkelen diskuterer vidare korleis prosess og resultat kan vurderast i deltakarbaserte kunstprosjekt generelt, og i dette prosjektet spesielt. Erfaringar frå Samarbeid mellom små og store vesen indikerer ei gjensidig avhengigheit mellom estetiske og sosiale aspekt. Artikkelen problematiserer difor om det estetiske let seg skilja frå det sosiale i kvalitetsvurderingar, mellom anna med referanse til Claire Bishop, Grant Kester og David Bell.

\footnotetext{
${ }^{1}$ Førsteamanuensis i sosiologi, Institutt for medie- og samfunnsfag, Universitetet i Stavanger merete.jonvik@uis.no
} 
Merete Jonvik. Eit skilt som prøver å vera eit skilt.

Nøkkelord: kunstproduksjon, deltaking, deltakarbasert kunst, horisontalitet, samarbeid mellom born og vaksne.

\section{Innleiing}

Samarbeid mellom små og store vesen er eit kunst- og forskingsprosjekt, der ein profesjonell kunstnar og ni born samarbeida om å skapa eit kunstverk. ${ }^{2}$ Intensjonen med prosjektet var å utforska om likeverd og horisontalitet i kunstproduksjon er mogleg, og i så fall på kva måtar, og å undersøka kva som kjem ut av eit samarbeid om kunstproduksjon beståande av asymmetriske relasjonar. Kunstnaren gjorde forsøk på å leggja til rette for flat struktur og frie formar for deltaking og samskaping. Produksjons- og samarbeidsprosessen vart dokumentert og analysert av underteikna. Spesiell merksemd var retta mot deltakarstrategiar, samarbeidsformer, makt og ansvar, samt verkproduksjon. Samarbeid mellom små og store vesen er inspirert av eit kunstnarisk samarbeid frå 2009 mellom kunstnar og professor ved Kunsthøgskolen i Oslo Ane Hjort Guttu og sonen hennar, Einar, som på tidspunktet for samarbeidet var sju år. Både Guttu og dokumentasjonsmaterialet som finst om samarbeidet og utstillinga det resulterte $\mathrm{i}$ - som etter kvart fekk namnet Natur/Utstilling (Guttu, 2018) - fungerer gjennomgåande som analytisk sparrepartnar i artikkelen ${ }^{3}$. Korleis påverkar den i utgangspunktet asymmetriske relasjonen mellom kunstnar og born, kunstproduksjonen? Kva formar for samarbeid viser seg? Kva verk blir skapt og korleis vurdera dette? Er sosialt og estetisk likeverd i deltakarbaserte kunstproduksjonar utopisk?

\footnotetext{
2 Kunst- og forskingsprosjektet vart gjennomført i perioden 2018-2019 og er eit samarbeid mellom kunstnar Hans Edward Hammonds, forskar Merete Jonvik og ei gruppe på ni born.

3 Takk til Ane Hjort Guttu for å ha lest og kommentert på eit tidleg utkast av artikkelen.
} 
Merete Jonvik. Eit skilt som prøver å vera eit skilt.

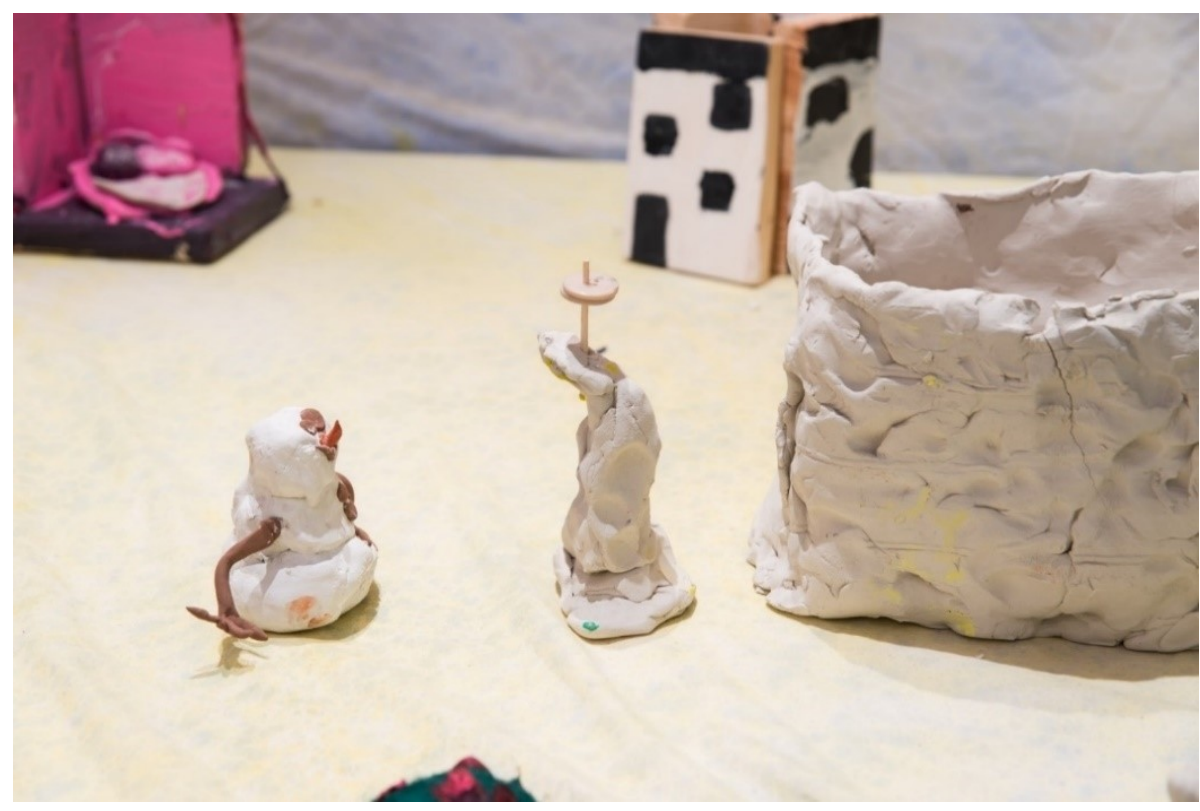

Figur 1. Samarbeid mellom små og store vesen, 2018. Foto: Hans Edward Hammonds

\section{Deltaking og horisontalitet}

Mykje merksemd i kunstfeltet har dei siste åra vore retta mot aktiv involvering $\mathrm{i}$ plassen for passiv mottaking, mot deltakarbasert kunstproduksjon, horisontalitet, deling og samarbeid på tvers (sjå til dømes Anderson, 2010, Bishop, 2004 \& 2012, Danbolt, 2014, Jonvik, Røssaak, Stien \& Sunnanå, 2020). Mange kunstnarar arbeider med kunst som inviterer til høg grad av medverknad og deltaking frå publikum (Eeg-Tverbakk, 2014, s. 46). Nye grupper vert invitert inn i kunstproduksjonen. Makt, kontroll og autonomi vert med dette re-distribuert til andre enn kunstnaren sjølv, og deltaking frå andre enn kunstnarar set spor i kunsten. Både deltakarbasert kunst, så vel som mykje kunst i det offentlege rom, relaterer seg til større straumdrag i det kontemporære kunstfeltet som gjer forsøk på å opna opp kunstens relative autonomi, på å re-distribuera kunst-praksisen, -språket og ideologien tilbake til det såkalla kvardagslivet (Decter, 2013, s. 262).

Ifølgje kunsthistorikar Claire Bishop kan populariteten til deltakarbasert kunst tilskrivast trua på at det å arbeida med folk flest, svarar til, eller liknar meir demokratiske politiske prosessar (Bishop, 2012). Trua botnar i det at deltakarbasert kunst tilbyr ei form for kollektiv sosial erfaring, og at det difor kan vera ein direkte samanheng mellom deltaking i kunstprosjekt og sosial inkludering. Motivasjonar bak deltakarorientering i kunstprosjekt kan i følgje Huybrechts, Schepers \& Dreessen grupperast i tre: (1) der ein trur deltakinga leiar til sosial framgang av noko slag (motivasjonen er sosial og politisk), (2) der ein er interessert i tekniske eller 
Merete Jonvik. Eit skilt som prøver å vera eit skilt.

strukturelle fordelar (motivasjonen er 'betre produkt'), og (3) der ein stiller spørjeteikn ved eller utfordrar dominante strukturar og maktforhold (der motivasjonen er å driva kulturkritikk) (Huybrechts, Schepers \& Dreessen, 2014, s. 11). Uansett kan deltakarbasert kunst opna for at kunstnaren kan læra frå, bli utfordra av og bygga på innsiktene, erfaringane og praksisen til «nokon andre» (ibid., 12).

Når det gjeld (kvalitets)vurderingar av deltakarbaserte kunstprosjekt, står deltakinga (kven er deltakarane, kva type relasjonar vert danna, kva kjem ut av desse) og dei sosiale dimensjonane i eit mildt sagt uavklart forhold til dei estetiske dimensjonane. (For kritiske vurderingar av koplingar mellom deltakarbaserte prosjekt, sosiale utfall og estetisk verdi sjå t.d. Bishop, 2012, s. 18-26).

Deltakarbasert kunst og kunstproduksjon som involverer andre enn kunstnarar - det som òg vert omtala som sosialt engasjert kunst (sjå t.d. Kester, 2011) - står i opposisjon til vektlegginga av det sterke kunstnarsubjektet i det moderne kunstomgrepet. Understrekingane av korleis kunst blir til i sosiale samspel og som del av sosiale samarbeid er mange, og i aukande grad frå 1960-talet og utover (t.d. Becker, 1982, Bourdieu, 1993, Green, 2001). Trass i utfordringar av både kunstnarsubjektet og kunstobjektet, lever modernistiske idear om både estetisk autonomi og den særskild evnerike åleinejobbande kunstnaren vidare. Grant Kester er ein av dei som omtalar korleis nyare og sosialt orienterte praksisar redefinerer konvensjonelle konsept som autonomi (2011). Han omtalar eit skifte frå kunstproduksjon som noko som vert skapt på førehand og plassert framfor ein tilskodar, til kunstproduksjon som prosessar kjenneteikna av ulike formar for utveksling av kreativ arbeidskraft.

Eit sentralt grep for mange samtidskuratorar og kunstnarar etter 2010 i Noreg er forsøk på horisontalitet i både kunstproduksjon, -formidling og -samarbeid (Jonvik, Røssaak, Stien \& Sunnanå, 2020). Horisontalitet som idé og strategi handlar om å ikkje tvinga autoritative praksisar, forståingar og røyndomsoppfatningar over i produksjonar og presentasjonar. Det handlar om å heller gjera fors øk på å omrokkera, stilla kritiske spørsmål til og setja saman forståingar, deltakarar og praksisar på nye måtar. Teksten «Attempting horizontality», av kurator Rachel Anderson, står sentralt (2010). Innbakt i dette ligg at ein skal forsøka å utvikla ein mest mogleg «rettferdig organisering av en presentasjon i tilblivelse» (Anderson, 2010, sjå òg Jonvik, Røssaak, Stien \& Sunnanå, 2020). Anderson talar for å prøva potensialet i å jobba med ikkje-vertikale modellar: «to try not to impose our will, assumptions or agenda on another party and invite an open exchange that supports a fluid creative dialogue» (Anderson, 2010). Ho har trua på kunstens transformative 
Merete Jonvik. Eit skilt som prøver å vera eit skilt.

kraft og at ein gjennom å investera i tid og rom for utforsking av idear og utveksling av ferdigheiter, kan adressera og kanskje løysa spesifikke sosiale problem.

\section{Natur/Utstilling}

Ein vaksen og eit born, ei mor og ein son - Ane og Einar - ville laga ei utstilling saman. Denne tok form i heimen deira, med vernissage og utstillingstekst, og naboar og kjende vart invitert. Både heimlege bruksobjekt omplassert og sett i nye kontekstar, så vel som nylagde objekt, vart gitt plasseringar på bord og veggar i heimen. Utstillinga fekk namnet Natur/Utstilling, som var eit kompromiss mellom Einar og Ane sine synspunkt og ønskjer. Seinare har Guttu reflektert over samarbeidet, prosessen og utstillinga i ein tekst med same namn (Guttu, 2018).

Eit grunnpremiss Guttu la for arbeidet, influert av Paulo Freire og Jaques Ranciere, var at den eine parten, altså ho, ikkje skulle vera rettleiar og lærar og så å seia kontinuerleg fortelja sonen kva han burde gjera eller korleis han burde tenkja. Eit anna grunnpremiss var at både sonen og Guttu sine idear om kva ei kunstutstilling er og kan vera skulle takast alvorleg. Det skulle vera kunstnarisk interessant både for Einar, som den han var på det aktuelle tidspunktet og det han var interessert i, og for Guttu, med hennar profesjonelle karriere og kunstsyn på tidspunktet. Guttu erkjenner at ho kom inn i samarbeidet med dobbelt opp av kulturell og strukturell kapital. Asymmetrien mellom dei låg både i at ho er mor og dermed kontinuerleg utøver makt og autoritet over Einar, og gjennom at ho er profesjonell biletkunstnar.

I samarbeidet mellom dei vart det stadige forhandlingar. Ei sak dei ikkje klarte å samarbeida om var utstillingstekst. Einar syntest ikkje dei trengde nokon tekst. For Ane var dette viktig. Ho tenkte at ho i denne kunne få formidla metaperspektivet ho hadde på samarbeidet og på utstillinga. Eit metaperspektiv som for ho nettopp utgjorde noko av det interessante ved prosjektet som kunstprosjekt. Utan metanivået var ho ikkje sikker på om ho kunne gå god for si eiga interesse og investering $\mathrm{i}$ prosjektet i kunstnarisk forstand.

I ettertid oppsummerer Guttu at ho og sonen hadde ulike forventningar til kva ei utstilling er og kan/må innehalda, ulike forståingar av deltakinga og ulikt referansegrunnlag. ${ }^{4}$ Tidvis såg Guttu si eiga rolle som ein «stramt regissert demonstrasjon i påtatt åpenhet» (Guttu, 2018, s. 84). At forsøka på å oppnå likskap og likeverd mellom dei to var ein form for spel som ho hadde makt til å styra i den

\footnotetext{
${ }^{4}$ Intervjusamtale mellom Ane Hjort Guttu, Hans Edward Hammonds og Merete Jonvik 29.05.2018.
} 
Merete Jonvik. Eit skilt som prøver å vera eit skilt.

retninga ho ville. Ho spør seg òg - som eit tankeeksperiment - om det er mogleg at asymmetrien kunne vore snudd på hovudet, og at sonen delegerte til mor å gjennomføra hans visjon og samstundes ga ho trua på at ho styrte prosjektet? I så måte, sett frå hans side, trengde han berre bryta inn eit par gongar, som då han i det stille fjerna ein sopp dei var ueinige om frå utstillingsbordet rett før opninga. Mor syns soppen var ein interessant kontrast til andre objekt i utstillinga. Sonen syns den var stygg.

I teksten om Natur/Utstilling relaterer Guttu til nokre av kjernespørsmåla for deltakarbasert kunst som dreier seg om makt. Ei drivkraft for slike prosjekt er gjerne «det demokratiske aspektet ved å gå inn i forpliktande samarbeid og overlate beslutninger til andre» (Guttu, 2018, s. 83). Kritiske perspektiv løftar fram korleis slike praksisar dekkjer over konfliktar, tek på seg oppgåver som burde vera andre sine (staten, fellesskapet) og underspelar estetikken. Sistnemnde kjem tydeleg fram i Bishop sin kritikk mot Nicolas Bourriaud si tilnærming til relasjonell kunst (Bishop, 2004 \& 2012, Bourriaud, 2007). «The quality of the relationships in 'relational aesthetics' are never examined or called into question. (...) all relations that permit 'dialogue' are automatically assumed to be democratic and therefore good. But what does 'democracy' really mean in this context?»(Bishop, 2004, s. 65). Relatert til dette peikar Guttu på at: «Relativt lite av den kritiske analysen har sett på graden av medbestemmelse i deltakelsen: Hvilke premisser folk deltar på og hvorvidt deltakerne framstår som nok ett av kunstnerens materialer» (Guttu, 2018, s. 83). Erfaringa frå kunstprosjektet med sonen gjer Guttu mistenksam overfor deltakande praksisar, og særleg dei som involverer lekfolk eller svake grupper. «Altfor ofte ser det ut til at deltakerne, som de gjerne kalles i kunstnernes dokumentasjon av prosjektene, er med kun i kraft av sin tilhørighet til en eller annen symbolsk kategori» (ibid.). Fara er stor, ifølgje Guttu, sjølv med medvit om det å unngå ei tradisjonell leiar/lærarrolle, for at denne rolla vert erstatta av ei meir sofistikert form for maktutøving der kunstnaren endar med å ta æra for både prosjektet og den demokratiske haldninga. I så fall snakkar vi om «usynlig manipulasjon framfor normal overkjøring» (ibid.).

\section{Store og små vesen: data og metode}

Samarbeid mellom små og store vesen vart utført i samarbeid med ein barneskule i Stavanger-området. Til saman ni born frå tredje trinn vart rekrutterte gjennom skulen, alle åtte år på tidspunktet. Borna hadde sjølv meldt si interesse for å delta, og lærarane på trinnet gjorde utval av kven som fekk vera med blant dei interesserte. Samarbeidet om kunstproduksjonen - som skulle enda i eit kunstverk plassert på skulen - vart lagt opp i fire samlingar i løpet av ein trevekers-periode hausten 2018. 
Merete Jonvik. Eit skilt som prøver å vera eit skilt.

Midtvegs vart det i fellesskap bestemt at det etter ferdigstilling skulle inviterast til vernissage for elevar og lærarar på tredje trinn ved skulen.

Datamaterialet til artikkelen skriv seg frå nærstudiar av samarbeidet mellom den vaksne profesjonelle kunstnaren, Hans Edward Hammonds ${ }^{5}$, og dei ni borna. Nærstudiane bestod av deltakande observasjon, intervju og samtalar, samt fotodokumentasjon. Deltakande observasjon er gjort av alle seansane der borna og Hammonds samarbeidde. Merksemd vart retta mot kunstnaren og borna sine måtar å jobba på, foreslå ting på, mot dynamikken som oppstod mellom store og små, vegval og utfordringar i arbeidet, samt synspunkt på verket. Intervjumaterialet består av fire intervjusamtalar med Hammonds og ein med Ane Hjort Guttu, samt ei rekkje uformelle feltsamtalar med Hammonds før, under og etter samlingane. I tillegg dekkjer intervjumaterialet ei rekkje feltsamtalar med borna. ${ }^{6}$ Desse dekkjer mellom anna samtalar om materialar, samarbeid, synspunkt på kunst med meir. Intervjua med Hammonds og Guttu er tatt opp og transkribert, medan det av personvernomsyn berre vart skrive notat av samtalar med borna. Intervjuguidane til samtalane med dei vaksne dekte tema som born og kunst, samarbeid, likeverd, skinndeltaking og deltaking, makt med meir. Verket og fotodokumentasjon av verket kan sjåast som del av datamaterialet. Samansetnad av objekt, plasseringar, formar og materialbruk stiller til skode val som er tekne undervegs og hintar om deltakarane sine kunstsyn, humoristiske sans og grad av medbestemming.

Empirien frå prosjektet er i artikkelen skriven ut sentrert til to tematiske spor 1) formar for samarbeid og det 2) å la vera som metode.

\section{Formar for samarbeid}

Når temaet er om likeverd er mogleg i konkrete situasjonar er det sentralt kva strukturelle og pragmatiske rammer som ligg på situasjonen og kven som har definert desse. I Samarbeid mellom små og store vesen var ei rekkje rammer lagt på

\footnotetext{
${ }^{5}$ Hammonds er ein norsk/new zealandsk kunstnar med Master of Fine Arts frå University of Auckland, New Zealand. Han jobbar med film, foto, tekstil, papir, installasjonar og performance, og driv kunstformidling for born og vaksne.

${ }^{6}$ Etisk knyt det seg nokre spesielle forhold til det å forska på born, m.a. knytt til føresetnadar for å gi informert samtykke til deltaking i forsking. Prosjektet er godkjend av Personvernombodet hos Norsk senter for forskingsdata. Informasjons- og samtykkeerklæring vart signert av foreldra til borna. Til borna vart det gitt tilpassa informasjon om dei same forholda. I prosjektet vart det ikkje samla inn personopplysningar om borna anna enn at det vart tatt bilete. Foreldre og born har godkjend at bilete av borna kan nyttast i formidling frå prosjektet.
} 
Merete Jonvik. Eit skilt som prøver å vera eit skilt.

førehand, sjølv om intensjonen var å utforska ikkje-styring, samarbeid og horisontalitet. Trass noko tidsmessig slingringsmonn, skulle kunstproduksjonen skje innanfor eit klart definert tidsrom og i avgrensa fysiske rom. Borna fekk klokkeslett innanfor skule- og SFO-tid der dei skulle møta i kunst- og handverksrommet på skulen sin. Materialval vart til ein viss grad gjort i fellesskap, men forslaga kom frå kunstnaren. Det enda med at vi brukte leire, maling, tre og tekstil, pluss at vi fekk tilgang til materiala som fantes i kunst- og handverksrommet. Borna presiserte at dei ville ha mykje av kvar. Mykje leire. Mykje maling. Mykje tekstil.

Borna tok forskjellige rollar i samarbeidet. Mest sannsynleg fordi dei kan, meistrar og trivst i ulike rollar i utgangspunktet. Truleg liknar desse på rollar dei tek i andre sosiale skulesamanhengar, men dei kan òg ha blitt påverka av den konkrete konteksten og dei konkrete andre som deltok i prosjektet. Nokre understreka og tvinga fram samarbeid, andre unngikk det. Nokre mista stadig konsentrasjonen og greip til leik, andre «forsvann» inn i eigne kreative rom og utforska materialar og teknikkar på eigenhand. Ei dreiv vyrdlaus omgang med maling og spurte bortimot aldri om råd eller hjelp. Ei anna jobba stillferdig og konsentrert med eit tekstilstykke, og oppsøkte sjeldan andre. Andre søkte støtte, råd og ros fleire gonger i timen. Ei jente tok raskt eigarskap til ideen om samarbeid, og trådde så å seia fram i «fråværet» av ein leiar/lærar. Vedkomande kommenterte gjerne verbalt undervegs: «no samarbeider vi godt», eller «sant du og eg samarbeider?». Eller ho inviterte andre til seg med orda: «er det nokon som vil samarbeida?», eller observerte: «no samarbeider nesten alle!». Dei to første samlingane jobba ho tett saman med ein annan elev, og spurde då etter stadfestingar av typen: «du samarbeider med meg, sant?». Etter kvart byrja den andre å trekka seg vekk med ord som: «eg samarbeider med alle», og til sist, då ho tydeleg kjende seg ufri: «det er du som samarbeider!». Etter dette jobba dei kvar for seg, utan at det er mogleg å registrera dårleg stemning mellom dei. Eleven som trådde fram i fråværet av vaksne «valde» ein strategi som provoserte fram understrekingar av når det skjer samarbeid, truleg for å møta det ho forstod som oss vaksne sine forventningar.

Ein annan elev «valde» ein radikalt annan strategi (i den grad dette er noko ein vel aktivt og bevisst, eller snarare grip til ubevisst etter kva rollar ein opplever er tilgjengelege, kva ein kjenner seg komfortabel med og korleis ein forstår situasjonen). Vedkomande prøvde aktivt å manøvrera seg vekk frå samarbeid for å konsentrera seg om eige solo-prosjekt. Han investerte så lite som mogleg i samarbeidsdelen, men til gjengjeld mykje i den kreative skapingsprosessen. På første samling hadde guten med seg ei teikning av ein kjend person som han namngav. Hammonds vurderer det som at guten ligg årevis framfor sine jamgamle i disiplinen teikning. Når 
Merete Jonvik. Eit skilt som prøver å vera eit skilt.

guten skal forma noko i leire vil han gjera ei leire-replika av teikninga si. Dette blir hans prosjekt. Han er detaljorientert og har god konsentrasjonsevne. Han rettar ikkje merksemd mot det dei andre lagar, spør ikkje «kva lagar du?», men held på med sitt. Han tek kontakt med Hammonds om det er ting han vil visa eller lurer på i forhold til sitt leireansikt. På fleire tidspunkt seier han at han aldri trur han har laga noko så bra i leire. På nest siste samling bryt han meir eller mindre plutseleg saman, og byrjar å grina. Etter kvart klarar han å fortelja at han har feila i fargeval då han skulle mala leireansiktet, på tidspunktet då ansiktet hadde nådd ei utforming han var veldig nøgd med. Guten er urokkeleg i sitt estetiske standpunkt om at fargen er feil. Hammonds trøystar og er einig i at fargevalet var feil, mellom anna fordi det skjulte konturane i ansiktet som han hadde jobba fram med stor detaljpresisjon. Guten vil ikkje bli inkludert i andre prosjekt den resterande tida, det einaste reelle valet for han ser ut til å vera å gå i gong med ein ny identisk versjon av leireansiktet, og så verkeleg skunda seg.

Desse to representerer ytterkantane av forsøk på (sjølv)styring i gruppa. Dei fleste jobba vekselvis på eigne underprosjekt og i flyktige samarbeid med andre, både medelevar og Hammonds. Utover i tredje samling byrja ei gruppe på tre-fire born å jobba tettare saman. Dei forma ei slags undergruppe. Alle i undergruppa jobba med leireobjekt som var figurasjonar av (hurtig)mat: pizza, pølse i brød, burrito, pommes frites. Samarbeidet verka skrida fram av at elevane i undergruppa hadde felles humor og fann glede i å forma nett dei objekta. Dei mora seg tydeleg, viste kvarandre kva dei var i ferd med å laga og spurte direkte og indirekte om stadfestingar. Ein av dei greip ei treramme som låg i rommet og forma ein pizzakiosk. Dei lagde òg eit skilt som kunne visa veg til kiosken (sjå figur 2). Ein gut i undergruppa utvikla tydeleg større eigarskap til ideen enn dei andre. Han byrja på eit tidspunkt mot slutten å tenkja fram mot det endelege verket og å posisjonera seg i forhold til å inkludera leireobjekta, som var figurasjonar av mat, på ein heilskapleg måte. Før dette tidspunktet hadde alle borna meir eller mindre arbeidd i noet, utan tanke for sluttproduktet eller det endelege verket. Dette står i sterk kontrast til Hammonds sine arbeidsstrategiar som konstant hadde dette som referanseramme, om ikkje aktivt uttala, så som underliggjande premiss i han sjølv. 


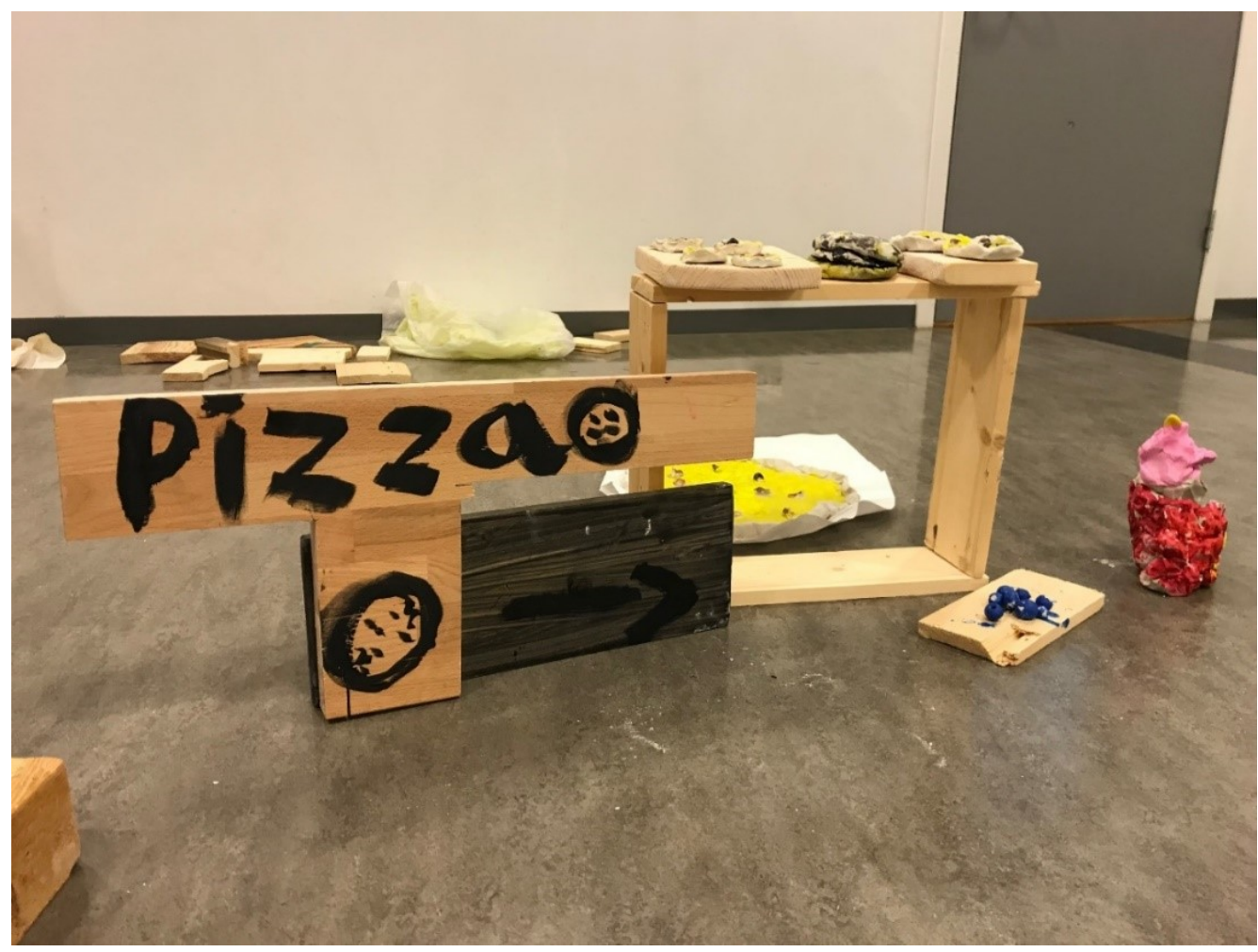

Figur 2. Samarbeid mellom små og store vesen, 2018. Foto: Merete Jonvik

\section{«Å la vera» som metode}

Ein styrande strategi for prosjektet var utforskinga av «å la vera» som metode, forsøk på ikkje-styring. Strategien tok form gjennom at Hammonds aktivt fors økte å tre ned frå autoritetsposisjonen sin som vaksen, lærar og profesjonell kunstnar, og la borna sleppa til på sine eigne premiss. På eigne premiss forstått som med deira eigne ord, preferansar og meiningar, forslag og innfall, føretrekte arbeidsmåtar og formar for kreativitet. Han forsøkte, som Guttu, i minst mogleg grad å ta rolla som lærar, og la produksjonen «skrida fram av seg sjølv», for i større grad å sleppa fram borna sine frie uttrykk. Han greip ikkje inn, fortalde ikkje kva som (ikkje) er mogleg, formidla ikkje om fargelære osb. Kunstnar Patricia Reed brukar omgrepsparet «hosting/un-hosting» om slike strategiar som dels overfører autoritet frå enkeltpersonar eller autoritetspersonar til andre deltakarar eller til gruppedynamikken i konkrete situasjonar: "Throughout the process of un-hosting a certain degree of control (not all) is dispersed and it is precisely that dispersion of 'control' that blurs conventional notions of authorship» (Goldenberg \& Reed, 2008).

Hammonds fortel at han gjennomgåande opplever det som vanskeleg å «un-hosta» fordi det inneber å avlæra at ein er vaksen, ikkje svara på spørsmål slik ein pleier, eller vera i verda slik ein pleier, med den høgda, dei erfaringane, refleksane og vokabularet ein til vanleg nyttar. Det inneber å ta mindre ansvar. Å forholda seg meir 
Merete Jonvik. Eit skilt som prøver å vera eit skilt.

passiv. Minska sin autoritet. Dette er òg utfordrande fordi han etter kvart kjenner på bekymring for progresjon, om dei i det heile kjem i land med eit verk. Han kjenner på ansvaret av å ha lova eit verk, som skal bli ein del av hans kunstnariske produksjon. Han kjenner på ansvar overfor borna at dei skal ha ok opplevingar av deltakinga og at alle skal kjenna at dei har bidratt, og han kjenner på ansvar overfor dei tilsette på skulen (lærarar, vaskepersonell og vaktmeister) for at rom og materialar vert godt skjøtta. Formar for ansvar som i seg sjølv gjer at likeverd synast utopisk. I tillegg: sjølv om borna tok seg meir til rette utover i samarbeidet, er det Hammonds dei oppsøkjer om dei vil ha tips, lurer på kor ting er, kva som er lov, vil ha ros, eller anna. Han slepp aldri unna rolla som vaksen autoritet. Til liks med erkjenninga til Guttu av at ho stilte i samarbeidet med sonen med dobbelt opp av kulturell og strukturell kapital, legg i tillegg prosjektansvar og forventningar til vaksne i skulesettingar føringar på kor langt det er mogleg å koma i forsøka på å oppnå likeverd i Samarbeid mellom små og store vesen.

\section{Eit skilt som prøver å vera eit skilt}

På tidspunktet då alle borna har laga fleire objekt, og undergruppa «pizzagjengen» byrjar å posisjonera sine objekt inn mot det endelege verket, fortel Hammonds at han slit med å omfamna skiltet og pizzakiosken estetisk. Han syns ikkje skiltet er fint (sjå figur 2), mellom anna fordi det er lite forseggjort, og fordi borna ikkje har investert tid og tanke i det. I tillegg er det «berre det du ser». Det er eit skilt som prøver å vera eit skilt. Han syns òg skalaforholdet er problematisk, ein burrito er like stor som ein husvegg om ein samanliknar med andre leireobjekt i verket. På sett og vis vart skiltet til pizzakiosken som soppen i Guttu og sonen sitt samarbeid. Hammonds syns skiltet var stygt og ville helst ikkje at det skulle bli del av verket. Hammonds og borna hadde med det ulike syn på kva som var verdig ein plass i utstillinga. I Natur/Utstilling ville Ane inkludera soppen fordi ho syns den representerte eit fint brot mot prinsippet om at det skulle vera objekt dei hadde laga sjølv. Einar syns soppen var ekkel og stygg og ikkje verdig til å vera med. Ane insisterte på å inkludera soppen, Einar fjerna den i stillheit rett før utstillinga. 
Merete Jonvik. Eit skilt som prøver å vera eit skilt.

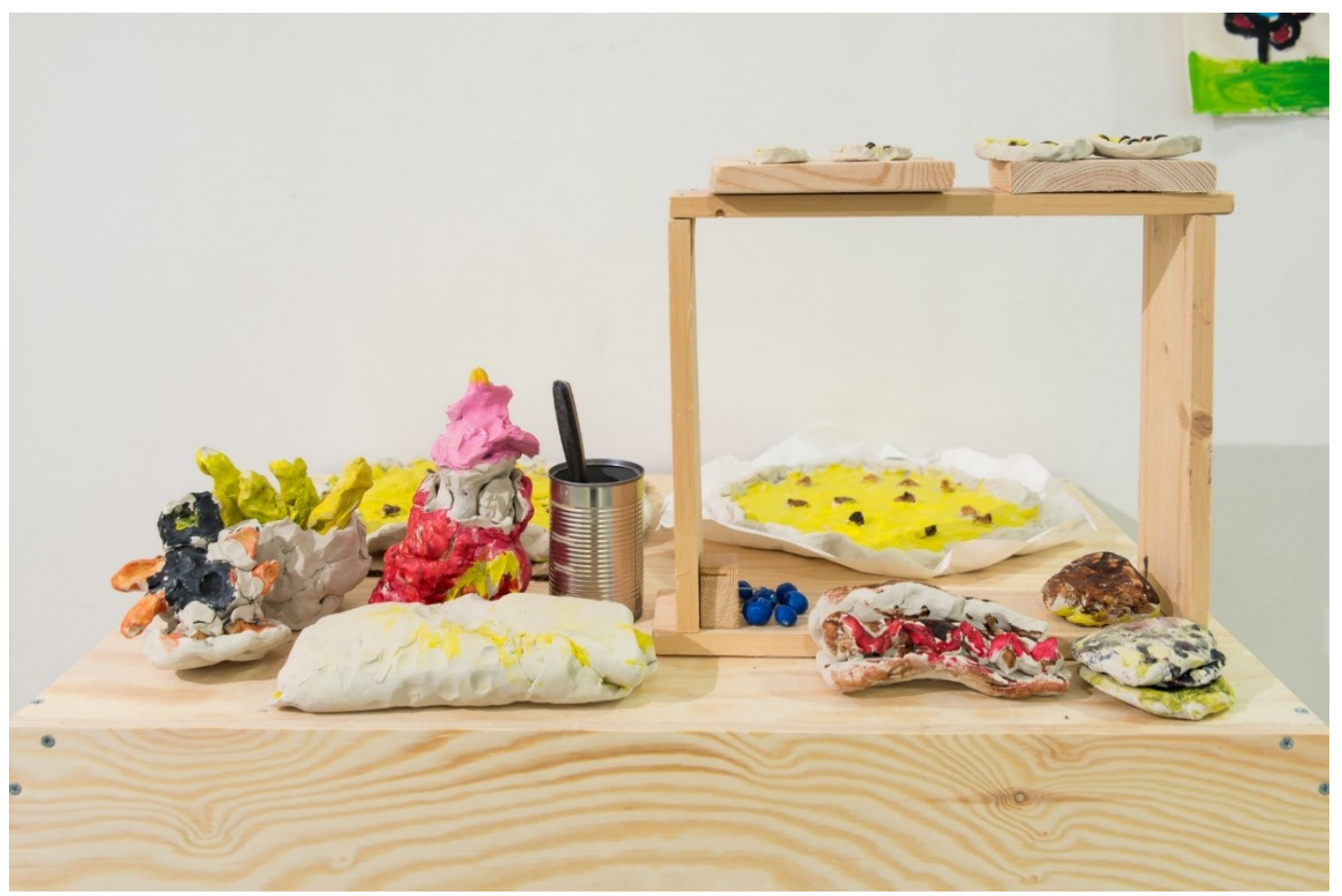

Figur 3. Samarbeid mellom små og store vesen, 2018. Foto: Hans Edward Hammonds.

I Samarbeid mellom små og store vesen enda det med at Hammonds var tru mot prosjektet si anti-autoritære tilnærming. Han overprøvde ikkje borna sine ønskjer og både skiltet og pizzakiosken vart med i det endelege verket (sjå figur 3 og 4). Men han fortel at han sleit med å akseptera at dei skulle vera med. I ettertid ytrar Hammonds at han i stadig større grad klarte å omfamna kiosken mellom anna fordi han forstod at det berre var han som hadde skala som markør og at han hadde låst seg fast i det dei hadde blitt einige om ved tidlegare høve. Han omtalar det som eit forløysande augeblikk då han skjønte at kiosken var borna sitt estetiske uttrykk (dvs. nokre av borna sitt uttrykk), og at dette åleine var grunn nok til at kiosken burde inkluderast. Det var deira uttrykk som skulle få plass gjennom «å la vera», ikkje «dei uttrykka Hammonds aksepterte var deira uttrykk». Etter denne erkjenninga kompenserte Hammonds med å foreslå at han kunne laga ein disk til pizzakiosken. Vidare vart det i fellesskap bestemt at kiosken skulle bli del av ein performance under opninga. I performancen tok borna kiosken i bruk, dei inviterte til kjøp og servering, og dei hadde utlodding. Denne «leiken med verket» vart svært godt tatt i mot blant publikum på opninga, sannsynlegvis fordi aktivisering ofte er kjærkome, men kanskje mest fordi det var deira medelevar som inviterte til leik, bruk og ei form for rollespel. Mange ville delta - stå i kø, handla, vinna, smaka. Det flokka seg rundt kiosken.

Når det gjeld vurdering av kvaliteten på det endelege verket (sjå figur 4), er forholda ovanfor sentrale i kunstnaren sine refleksjonar. Det er bruken av og interageringa $\mathrm{i}$ 
Merete Jonvik. Eit skilt som prøver å vera eit skilt.

verket han trekk fram. Han ser det som at rommet der verket vart plassert på skulen fekk eit stort løft, og 7.klasse-elevar ved skulen, som til dagleg nyttar rommet, ga fleire positivt vurderande tilbakemeldingar. Likevel er Hammonds sjølv kritisk til det ferdige verket. Bileta av verket utan borna i er dødt meiner han, på den måten at det ikkje viser energien som faktisk gjekk inn i arbeidet. Der prosjektet glimrar til og fann sin estetiske verdi, ifølgje kunstnaren sjølv, var på sjølve opninga eller vernissagen. Det var då borna tok i bruk verket. Pizzakiosken vart brukt i aktivitet og leik, og det vart arrangert ei moteframsyning der borna viste fram tekstilar dei hadde jobba med, som ei form for «wearable art». Der kiosken mangla kompleksitet og djupn, og var for bokstaveleg, som var Hammonds sine ankepunkt, fekk den sin verdi gjennom sosiale dimensjonar, gjennom bruk. Ifølgje Hammonds er det i bruken av og leiken med verket, i mylderet av uttrykk, og så og seia i fråværet av tydelege skilje mellom objekt og bruk, at han opplevde å vera nærast borna sine eigne (kunstnariske) uttrykksformer. Den estetiske omfamninga av kiosken opna seg for Hammonds gjennom dei sosiale forholda. Tyder det at han nyttar ein eigen vurderingsskala som ikkje rettar seg mot kunst skapt av vaksne profesjonelle? Eller indikerer det at sosiale dimensjonar og bruk er ein sentral del av vurderingsgrunnlaget for deltakarbasert kunst? Kanskje hadde borna heile tida sett skiltet for seg i bruk? Og at det gjennom det representerte noko meir enn det Hammonds såg?

\section{Estetiske og sosiale vurderingar}

Dette leier over i korleis ein skal vurdera om deltakarbaserte kunstprosjekt er vellykka. Med referanse til den kunstnariske produksjonen, til graden av deltaking, eller til begge? Skal vi i Samarbeid mellom små og store vesen vurdera verdien etter kor likeverdige partane klarte å bli i ulike situasjonar? Kor mange former for samarbeid som vart etablert? Eller skal vi vurdera prosjektet etter kor harmonisk og friksjonsfri vegen fram mot eit felles verk var? Eller det motsette, i kva grad motsetnadar og disharmoni oppstod? Eller skal prosjektet vurderast etter i kva grad kunstnaren klarte å «un-hosta» og gi frå seg autoritet kombinert med graden av deltaking frå borna? At jo meir borna deltok, jo meir ansvar dei tok, jo betre? Alle er interessante spørsmål, men dei har svake koplingar til dei estetiske sidene ved samarbeidet om kunstproduksjon. Dei kunne vore stilt til eit kva som helst prosjekt. Vurdering av deltakarbaserte kunstprosjekt bør vel òg ta for seg estetiske sider ved denne kunsten? Og korleis skal så estetiske presentasjonar i deltakarbaserte kunstprosjektet vurderast? Som eit kva som helst kunstverk? Det som treff born kunstnarisk, treff det òg vaksne? 
Merete Jonvik. Eit skilt som prøver å vera eit skilt.

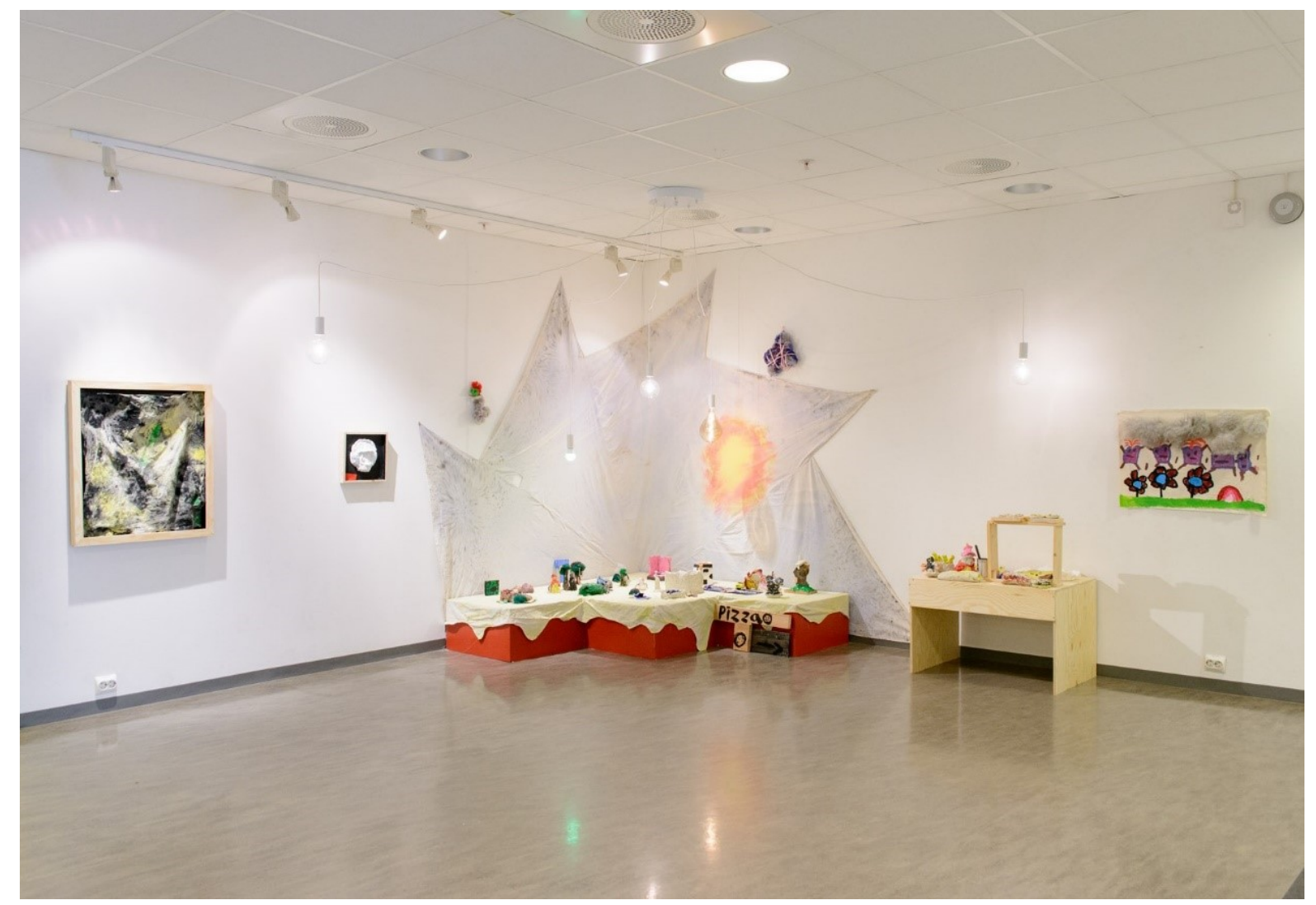

Figur 4. Samarbeid mellom små og store vesen, 2018. Foto: Hans Edward Hammonds

Samarbeid mellom små og store vesen la til rette for nye møter, reell interaksjon og samarbeid om skaping av kunst. Intensjonen med prosjektet var å utforska på kva måtar likeverd og horisontalitet i kunstproduksjon prega av asymmetriske relasjonar eventuelt er mogleg. Det kjem tydeleg fram at likeverd ikkje var i nærleiken av å verta oppnådd. Samarbeidet braut aldri laus frå sin asymmetri. Hammonds sine forsøk på «un-hosting» klarte ikkje å bryta ut av det faktum at han er vaksen, vart assosiert med lærarar og at borna tenkte på han som profesjonell kunstnar. Som sannsynlegvis ikkje er på grunn av kunstnaren sine særtrekk eller manglande evner, men på grunn av dei bindingar og forventningar som konteksten og alle involverte sine tidlegare erfaringar legg på situasjonen (konteksten som var ein skule, forventningar ein har til vaksne folk $\mathrm{i}$ klasserom, autoriteten som ligg i vaksenrolla normalt sett m.m.). Fors øka strakk seg eit stykke, men enda meir som forsøk på enn som faktisk horisontalitet. Moglegheita for sosialt likeverd forblei av desse grunnane utopisk.

For Guttu sin del, med referanse til Natur/Utstilling, konkluderte ho med at det var på det estetiske nivået, i objekta si stilling i utstillinga, og ikkje på det sosiale nivået, at tillaup til likeverd vart oppnådd. Ho skriv: «(...) møtene fant sted i et åpent, mangetydig rom uten fors $ø k$ på å forklare, forhandle eller forene. Det var altså som 
Merete Jonvik. Eit skilt som prøver å vera eit skilt.

om forsøkene på samarbeid imploderte, mens de tause treffpunktene mellom objektene selv kunne uttrykke de likeverdige møtene som manglet i prosessen» (Guttu, 2019, s. 85). Tillaupet til likeverd var langt større i den estetiske presentasjonen enn i det sosiale samarbeidet òg i Samarbeid mellom små og store vesen. Det endelege verket (sjå figur 4) er sett saman av ei rekkje objekt som varierer med omsyn til storleik og skala, figurasjon og abstraksjon, tidsinvestering, teknikk og materialkombinasjonar, der ein ikkje naudsynleg ser kven som har laga kva, eller at nokre enkeltobjekt eller idear stikk seg veldig ut. Det som likevel kjem tydelegast fram frå Samarbeid mellom små og store vesen er ei problematisering av om det estetiske let seg skilja frå det sosiale. Hammonds oppsummerer at det er i sosial omgang med verket, når verket vert tatt i bruk, at det kjem til sin rett, eller skimtar med estetisk verdi. Bileta av verket utan born i er dødt og tomt, medan bileta med borna som agerer i og brukar verket til ein viss grad reflekterer noko av energien i samarbeidet og i rommet under opninga, då verket vart tatt i bruk, og tatt ut i leik (sjå figur 5). Kan då verket vurderast utan bruken? Utan kjennskap til prosessen? Utan vurdering av at det var akkurat desse personane, med deira relasjonar seg imellom, som arbeidde fram verket?

Ei vidare drøfting av verdien og kvaliteten av verket frå Samarbeid mellom små og store vesen og deltakarbaserte kunstprosjekt meir generelt, kan trekka vekslar på ulike teoretiske og praksisbaserte perspektiv. To relevante ytterkantar i så måte kan vera Claire Bishop og Rachel Anderson sine perspektiv på deltakarbasert kunst. Bishop rettar som nemnd hard kritikk mot sosialt orientert kunst, og relasjonell kunst, primært fordi den ikkje er kompleks og kritisk nok (2004). Ho kritiserer det at deltakarbaserte kunstprosjekt og -praksisar meir eller mindre automatisk blir vurdert som demokratiske og gode, fordi dei legg til rette for dialog og legg til rette for nye sosiale møte (Bishop, 2004, s. 65). Som ein konsekvens av dette, hevdar Bishop, blir estetiske dimensjonar sett til side, i plassen for moralske, etiske og sosiale vurderingar. Ho etterspør større kritisk sensitivitet knytt til dei faktiske relasjonane i deltakarbaserte kunstprosjekt. Med Bishop si kritiske høg-teoretiske tilnærming fell truleg Samarbeid mellom små og store vesen i unåde fordi «reine» estetiske dimensjonar vert skyvd såpass langt til side, og ein står att med eit demokratisk velgjerande prosjekt. Sett gjennom dette perspektivet vert det nærliggande å retta kritiske blikk mot kva verdi dei flyktige møta mellom kunstnaren og dei ni borna eigentleg kan ha. Er det mogleg å tala om eit fellesskap i det heile, flyktigheita og asymmetrien tatt i betraktning? Iscenesettar vi eigentleg ei skinndeltaking? Eller, om det er reell deltaking, er ikkje premissa for korleis deltakarane kan delta i stort monn lagt på førehand, gitt avgrensingane i tid og rom? Den vaksne kunstnaren kunne heile vegen enkelt setja foten ned, og med det endra reglane i rommet, i kraft av si 
Merete Jonvik. Eit skilt som prøver å vera eit skilt.

rolle. Det kunne ikkje borna. Ei nærliggande innvending i så måte blir om vi iscenesettar ei tilgjort re-fordeling av makt som berre skjer isolert i rommet det blir utforska i, og ikkje har nokon konsekvens utanfor det same rommet.

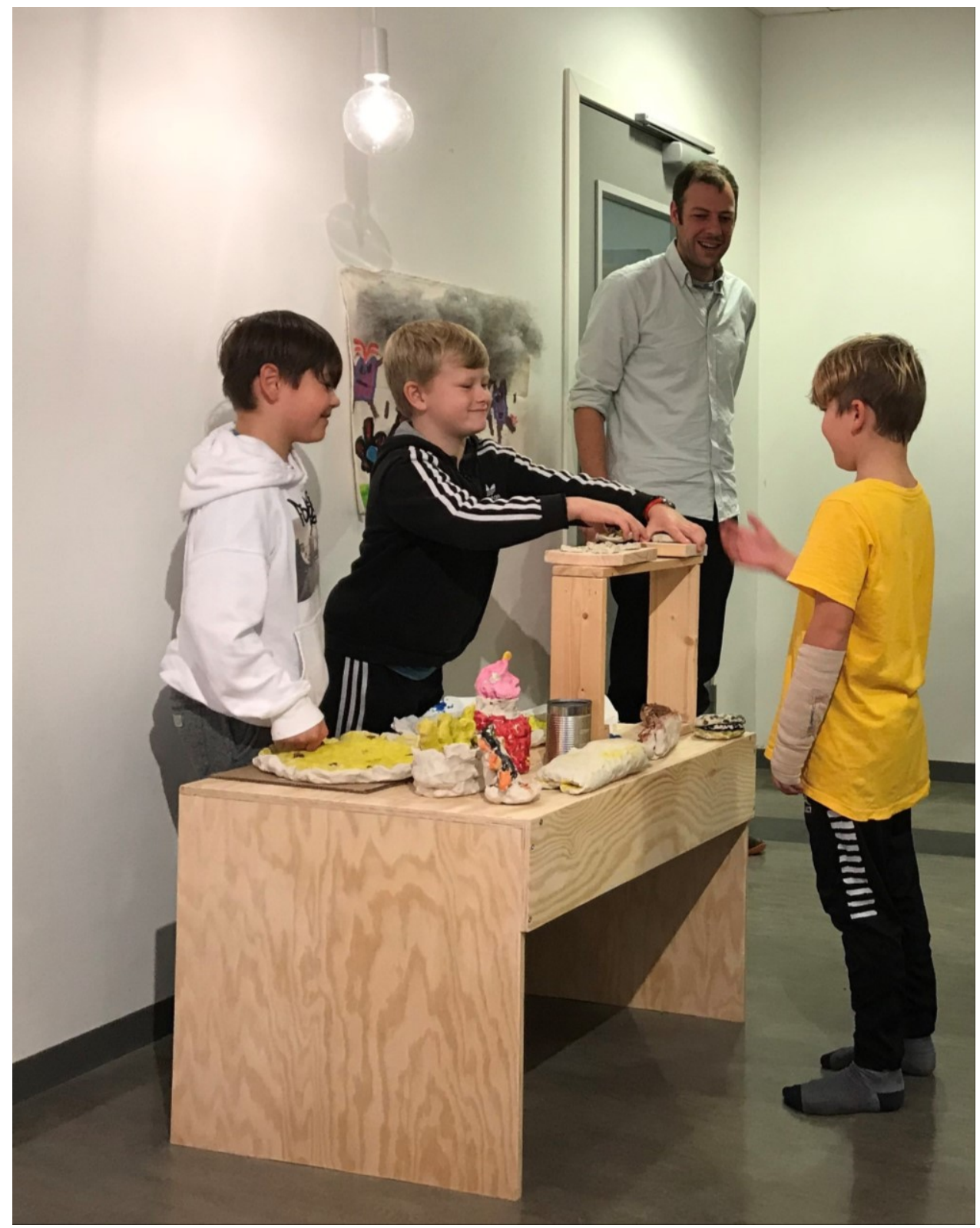

Figur 5. Samarbeid mellom små og store vesen, 2018. Foto: Merete Jonvik

I ein annan form for ytterkant, kan vi sjå prosjektet vårt gjennom eit meir praksisnært perspektiv, inspirert av kurator Rachel Anderson. I teksten «Attempting horizontality» talar ho for å prøva potensialet i å jobba med ikkje-vertikale modellar: å prøva å ikkje overføra eigen vilje og agenda på andre, og heller invitera til open utveksling (Anderson, 2010). Med Anderson si praksisbaserte tilnærming vil truleg intensjonen i forsøka på å ikkje overføra eigen vilje og agenda på andre, og forsøka på - gjennom 
Merete Jonvik. Eit skilt som prøver å vera eit skilt.

kunst - å invitera til open utveksling og kreativ dialog, bli tillagt verdi. I Samarbeid mellom små og store vesen vart det skapt eit verk som ikkje liknar noko anna kunst eller andre objekt som finst ved skulen. Verket trakk til seg merksemd frå langt fleire enn dei som deltok. Alle deltakarane - sjølv om dei ikkje var i nærleiken av likeverdige - tok med seg erfaringar frå prosjektet som variantar av sosialt samvær, tett samarbeid og utveksling på tvers av klassar på skulen. Ikkje minst vart det lagt til rette for kunstnarisk produksjon og leik i eit rom med langt større moglegheiter for fri utfalding og materialeksperimentering enn tradisjonelle kunst- og handverkstimar normalt legg til rette for. Alle involverte tok med seg både estetiske og sosiale erfaringar frå prosjektet, og alle fekk tilgang til noko som var større enn dei hadde sjølve, ei triviell, men i denne samanheng sann frase. Med referanse til sistnemnde kan det likevel tenkjast at det største læringspotensialet ligg hos kunstnaren. Hammonds fekk utfordra sin eigen måte å arbeida på gjennom å testa ut nye strategiar. For han ligg det læringsverdi i å vera tvungen til å akseptera syn, praksisar og avgjerder som er langt frå sine eigne. For borna - som viste stor glede over å få delta - «Tenk at vi får vera med på dette prosjektet!» - og som oppsummerte det som «kjekt» - likna nok prosjektet meir på frie og annleis kunst- og handverkstimar, med langt større tilgang på materialar og rom for utfalding. Truleg gjeld dette skeivforholdet generelt for samarbeid prega av asymmetri. Verdien i å inkludera nye perspektiv og tilnærmingar er størst for den som «har makta» og inviterer inn, og som dermed gjerne legg premissa, samanlikna med den som «ikkje har makta, men som vert invitert inn på den inviterande sine premiss, og som kan bidra med noko nytt og «sprenga grenser» berre om den som har mest makt (som har gitt frå seg litt), tillèt det. Ein kritisk merknad i så måte er at berre «den store» i Samarbeid mellom små og store vesen tek erfaringane med seg i sitt profesjonelle virke, og kan utnytta og profittera på inkluderinga.

Forsøk på å minimera kunstnarsubjektet - som la-vera-strategiar og «un-hosting» handlar om - bringer òg fram spørsmål om grenser for opphavsrett og autonomi. Deltaking og deltakarbasert kunst har endra kunstomgrepet, verkomgrepet og kvalitetsvurderinga. Det er etter kvart openbart at ein ikkje er tent med om deltaking vert sett på som eit gode i og for seg sjølv, og liknande, om estetisk autonomi i og for seg sjølv er einaste vurderingskriterium. I The One and the Many skriv Kester om korleis nyare deltakarorienterte praksisar kompliserer konvensjonelle syn på estetisk autonomi (Kester, 2011, s. 9-10). Han hevdar at desse har leia samtidskunsten (og kunstproduksjonen) gjennom eit paradigmeskifte. Ikkje ved at sosialt engasjert deltakarbasert kunst overgår objekt-orienterte praksisar, heller ved at: «They simply offer a different articulation of a capacity that I take to be central to the constitution of modern art more generally: the ability of aesthetic experience to transform our 
Merete Jonvik. Eit skilt som prøver å vera eit skilt.

perceptions of difference and to open space for forums of knowledge that challenge cognitive, social or political conventions» (2011, s. 11). Kester opnar for at desse kunstpraksisane og kunsten som kjem ut av dei kan gi andre typar estetiske opplevingar som på andre måtar artikulerer kva som er kunstens kapasitetar. I Conversation Pieces lanserer Kester omgrepet dialogisk estetikk, og talar mot at ein kvar diskusjon og re-definering av estetisk autonomi vert sett som ei avvising av estetikk per se, og for at ein gjennom dialogisk estetikk kan henta fram meir nyanserte forståingar av den gjensidige avhengigheita mellom det estetiske, det politiske og det etiske (Kester, 2013 [2004], XVII-XVIII). Bishop på si side har uttalt at ho meiner at kunstnaren sitt ansvar ikkje ligg i det å minimera si makt vis-a-vis deltakarane, men heller å skapa «unease, discomfort... frustration... fear, contradiction, exhilaration and absurdity» (Bishop, 2006, s. 26, Bell, 2017, s. 74). Bishop ønskjer seg òg fokus på « ... the effects of collaborative art for those who encounter its results but do not engage in its immediately collaborative phase» (Bell, 2017, s. 81). I forlenginga av dette understrekar David Bell, i si samlesing av Bishop og Kester, at det i diskusjonen mellom dei to vert skapt ein uheldig binær opposisjon mellom affirmasjon og negasjon (stadfesting og kritikk). I staden ønskjer han seg meir utforsking av korleis deltakarbasert kunst simultant kan både kritisera og utfordra status quo («negate») og stadfesta og lansera («affirm») alternativ til det (ibid.). Erfaringar frå Samarbeid mellom små og store vesen tydeleggjer den gjensidige avhengigheita av det estetiske og det sosiale, samstundes som det kjem klart fram at forsøka på spreiing av kontroll, minimering av autoritet og utfordring av maktrelasjonar i kunstproduksjon, gjorde grenser for opphav, verk, autonomi og kvalitet meir utydelege. Kanskje ligg det verdi òg i det?

Prosjektet er støtta av Norsk Kulturråd.

\section{Forfattaromtale}

Merete Jonvik er førsteamanuensis i sosiologi ved Institutt for medie- og samfunnsfag, Universitetet i Stavanger. Ho tok doktorgraden ved same universitet med avhandlinga Folk om forskjellar mellom folk (2015). Avhandlinga er ei utforsking av korleis folk frå ulike samfunnslag oppfattar og kommuniserer sosiale og kulturelle forskjellar. Jonvik sine forskingsfelt er innan kunst- og kultursosiologi, sosial ulikskap og levekår.

\section{Referansar}

Anderson, R. (2010). Attempting Horizontality. Henta frå http://www.rachelanderson.info/uploads/2/1/0/0/21003736/quam paper.pdf 
Merete Jonvik. Eit skilt som prøver å vera eit skilt.

(lest 14.10.2018).

Becker, H. S. (1982). Art Worlds. Berkeley/Los Angeles/London: University of California Press.

Bell, D. M. (2017). The Politics of Participatory Art. Politics Studies Review, Vol 15(1): 73-83. DOI: https://doi.org/10.1111/1478-9302.12089

Bishop, C. (2004). Antagonism and Relational Aesthetics. I Krauss, R. et al. October 110: 51-79, New York: MIT Press Journals. DOI:

https://doi.org/10.1162/0162287042379810

Bishop, C. (2012). Artificial Hells. Participatory Art and the Politics of Spectatorship. London og New York: Verso.

Bourdieu, P. (1993). The Field of Cultural Production. Cambridge/Oxford: Polity Press.

Bourriaud, N. (2007 [1998]). Relasjonell estetikk. Oslo: Pax Forlag A/S.

Danbolt, G. (2014). Kunst og barn i et historisk perspektiv. I Røyseng, S., Pettersen, A. T. \& Habbestad, I., Begreper om barn og kunst, Oslo: Norsk Kulturråd.

Decter, J. (2013). Art is a Problem. Selected Criticism, Essays, Interviews and Curatorial Projects (1986-2012), Document Series, JRP Ringier.

Eeg-Tverbakk, P. G. (2014). De raddeste av de radde bruker fontenen som gap. I Røyseng, S., Pettersen, A. T. \& Habbestad, I., Begreper om barn og kunst, Oslo: Norsk Kulturråd.

Goldenberg, D. \& Reed, P. (2008). What is a Participatory Practice?, I Fillip 8. Henta frå https://fillip.ca/content/what-is-a-participatory-practice (lest 09.01.2019).

Green, C. (2001). The Third Hand. Collaboration in Art from Conceptualism to Postmodernism. University of Minnesota Press.

Guttu, A. H. (2018). Natur/Utstilling. I Guttu, A. H., Tekster. Samtaler. Manus. Oslo: Torpedo Press.

Huybrechts, L., Schepers, S. \& Dreessen, K. (2014). Participation and Risky Tradeoffs. I Huybrechts, L. (ed.) Participation is Risky. Approaches to Joint Creative Processes. Amsterdam: Valiz.

Jonvik, M., Røssaak, E., Stien, H. H. \& Sunnanå, A. (2020). Kunst som deling, delingens kunst. Bergen: Fagbokforlaget.

Kester, G.H. (2013 [2004]). Conversation Pieces. Community and Communication in Modern Art. Berkeley, Los Angeles, London: University of California Press.

Kester, G.H. (2011). The One and the Many. Contemporary Collaborative Art in a Global Context. Durham, London: Duke University Press. Kester, G.H. (2011). https://doi.org/10.1215/9780822394037 